\title{
Aqueous Stem Bark Extract of Spathodea campanulata (P. Beauv) Modulates Carbon Tetrachloride Induced Hepatic Damage in Rats
}

\author{
${ }^{1}$ Charles Ansah, ${ }^{1}$ Phyllis Elsie Dadzeasah and ${ }^{2}$ Emmanuel Asiamah \\ ${ }^{1}$ Department of Pharmacology, Faculty of Pharmacy and Pharmaceutical Sciences, College of Health Sciences, \\ Kwame Nkrumah University of Science and Technology, Kumasi, Ghana \\ ${ }^{2}$ Department of Histopathology, Komfo Anokye Teaching Hospital, Kumasi, Ghana
}

Received 2012-09-24, Revised 2013-05-22; Accepted 2013-05-27

\begin{abstract}
The objective of the present study was to evaluate the hepatoprotective and curative potential of the aqueous extract of the stem bark of Spathodea Campanulata (SCE) in a carbon tetrachloride-induced model of hepatotoxicity in rats. Rats pre-treated with $625 \mathrm{mg} \mathrm{kg}^{-1}, 1250,2500 \mathrm{mg} \mathrm{kg}^{-1}$ or silymarin $\left(50 \mathrm{mg} \mathrm{kg}^{-1}\right)$ p.o for 3 days were intoxicated with $\mathrm{CCl}_{4}\left(1 \mathrm{~mL} \mathrm{~kg}^{-1}, 20 \%\right.$ in liquid paraffin, p.o). In curative studies, rats received $\mathrm{CCl}_{4}\left(1 \mathrm{~mL} \mathrm{~kg}^{-1}, 20 \%\right.$ in liquid paraffin, p.o daily) for 5 days before treatment with 100,300 and $625 \mathrm{mg} \mathrm{kg}^{-1}$ or silymarin $50 \mathrm{mg} \mathrm{kg}$ p.o daily for 3 days. In both the prophylactic and curative studies, significant hepatoprotective effects were obtained against liver damage induced by carbon tetrachloride as evident from decreased serum levels of Aspartate Aminotransaminase (AST), Alanine Aminotransferase (ALT), Gamma glutamyl transferase and bilirubin in the SCE treated groups $\left(100,300,625 \mathrm{mg} \mathrm{kg}^{-1}\right)$ and the silymarin group compared to the intoxicated controls. These results correlated well with the histopathology of liver for treated and control groups as well as the antioxidant protective capacity. The extent of lipid peroxidation assayed showed that TBA reactive substances increased significantly (six fold) in the carbon tetrachloride treated animals compared to the control. Treatment with the extract however restored TBA reactive substances to near normal at all three doses compared to the control. Additionally, the presence of phenols and the reducing power of the extract confirmed the antioxidant protective effect suggested by the reduction in lipid peroxidation. Administration of the extract (p.o) for seven consecutive days also significantly inhibited cytochrome P450 enzymes. The inhibitory effect on $\mathrm{P} 450$ enzymes possibly interfered with $\mathrm{CCl}_{4}$ bioactivation and thus protected the hepatocytes. The present study thus suggests that aqueous stem bark extract of Spathodea campanulata significantly reverses $\mathrm{CCl}_{4}$ hepatic damage in rats.
\end{abstract}

Keywords: Spathodea Campanulata, Carbon Tetrachloride $\left(\mathrm{CCl}_{4}\right)$, Hepatoprotective Effect

\section{INTRODUCTION}

Spathodea campanulata, commonly referred to as African Tulip tree or Flame tree is located in the rainforest of equatorial Africa (Joly, 1985). The aqueous extract of Spathodea campanulata (P. Beauv) stem bark is reportedly used traditionally almost as a panacea. The bark infusion is used to treat dysentery and stomach ache; rubbings from the bark in treating oedemas, skin diseases including herpes and for wound healing (Mensah et al., 2006). It is also used to treat kidney disorders (Abbiw, 1990), as well as insulin and non-insulin dependent diabetes in Rwanda (Niyonzima et al., 1999).

The widespread use of Spathodea campanulata in traditional medicine has prompted biological and pharmacological studies into the plant over recent years. Spathodea campanulata stem bark decoction has shown a hypoglycaemic activity in Streptozotocin (STZ)

Corresponding Author: Charles Ansah, Department of Pharmacology, Faculty of Pharmacy and Pharmaceutical Sciences, College of Health Sciences, Kwame Nkrumah University of Science and Technology, Kumasi, Ghana 
induced diabetic mice (Niyonzima et al., 1999) and also demonstrated activity on Plasmodium berghei in mice (Makinde et al., 1988). It has also shown antibacterial activity against $B$. subtilis, E. coli, P. aeruginosa and $S$. aureus (Mensah et al., 2006; Ofori-Kwakye et al., 2009).

The use of Spathodea campanulata in traditional medicine has also been supported by the isolation and identification of some active chemical constituents including spathodol, (a new dihydroxylated sterol isolated from the leaves of Spathodea campanulata), oleanolic acid and pomolic acid (Mbosso et al., 2008). Flavonoids, triterpenoids, diterpenoids and caffeic acid derivatives are also reported present in different parts of the plant (Houghton et al., 2005).

While liver diseases continue to be a problem worldwide, conventional medications available for the management of liver diseases are limited. Among the drugs for liver injury, silymarin (a plant based preparation from Silybum marianum) is the most clinically popular in Europe (Kim et al., 2007; Lieber et al., 2003). Interestingly, orthodox medications for liver disorders are mainly from plant sources (Orhan et al., 2007). Therefore the search for potent hepatoprotective agents from botanical sources is worthwhile.

We observed in a general toxicity assessment of Spathodea campanulata that treatment of rats with the aqueous stem bark extract of the plant profoundly reduced the ALT levels in rats (unpublished). We therefore reasoned that Spathodea could probably have a role in the management of liver diseases. The carbon tetrachloride-induced liver damage model, a model with extensive use and acceptability (Tsai et al., 2008) was used in the study. Here we report on the prophylactic and curative effects of an aqueous extract of Spathodea campanulata on liver injury induced by carbon tetrachloride in rats.

\section{MATERIALS AND METHODS}

\subsection{Chemicals/Reagents}

Carbon tetrachloride, Sodium Dodecyl Sulphate, Acetic acid, Thiobarbituric Acid, Pyridine, n-butanol, 1,1,3,3-tetramethoxypropane, formalin and Sodium dihydrogen phosphate were purchased from Sigma (St. Louis, MO, U.S.A.), Silymarin, named Legalon 70 (from Bukwang Param, Seoul, Korea), was purchased from Bandy Chemist, a pharmaceutical company in Kumasi, Ghana.

\subsection{Animals}

The animals used in the study, Sprague-Dawley rats $(150-220 \mathrm{~g})$, were purchased from the Noguchi Memorial Institute for Medical Research, University of Ghana, Legon, Accra, Ghana and were maintained in the Animal house of the Department of Pharmacology, Kwame Nkrumah University of Science and Technology (KNUST), Kumasi. The animals were housed in groups of 6 in stainless steel cages $(34 \times 47 \times 18 \mathrm{~cm})$ and fed with normal commercial pellet diet (GAFCO, Tema), given water ad libitum. Approval for this study was obtained from the Ethical Review Committee, Department of Pharmacology, College of Health Sciences, Kwame Nkrumah University of Science and Technology, Kumasi, Ghana.

\subsection{Preparation of Extract}

Spathodea campanulata stem bark was collected at Kotei, a suburb of Kumasi near Kwame Nkrumah University of Science and Technology, Kumasi, Ghana in the month of October, 2008 and authenticated by Dr. Kofi Annan a Pharmacognosist at the Department of Pharmacognosy, Kwame Nkrumah University of Science and Technology, Kumasi, Ghana.

The stem bark was cut into smaller pieces and sun dried for nine days. The dried stem bark was milled in a hammer mill. The powdered stem bark $(1000 \mathrm{~g})$ was then extracted by decoction in water $(3000 \mathrm{~mL})$ for $30 \mathrm{~min}$ and the extract freeze-dried at the Centre for Scientific Research into Plant medicine, Mampong Akwapim, Ghana. The yield was $12.7 \% \mathrm{w} / \mathrm{w}$. The freeze-dried extract, herein referred to as Spathodea or SCE, was then stored in a desiccator and was reconstituted in water immediately prior to use.

\subsection{Effect of Spathodea on Carbon Tetrachloride Induced Hepatotoxicity}

\subsubsection{Prophylactic Studies}

This part of the study was conducted to assess the hepatoprotective action of SCE against $\mathrm{CCl}_{4}$ induced liver damage. Thirty (30) rats were divided into six (6) groups $(\mathrm{n}=5)$. SCE $\left(625,1250,2500 \mathrm{mg} \mathrm{kg}^{-1}\right)$ and silymarin $\left(50 \mathrm{mg} \mathrm{kg}^{-1}\right)$ were administered by oral gavage to the first four groups (A,B,C,D) at 48,24 and $2 \mathrm{~h}$ before $\mathrm{CCl}_{4}\left(20 \%\right.$ mixed with liquid paraffin, $1 \mathrm{~mL} \mathrm{~kg}^{-1}$ p.o) administration. Group $\mathrm{E}$ was given only vehicle and group $\mathrm{F}$ received the same dose of $\mathrm{CCl}_{4}$ to serve as the toxin control (Bremanti et al., 1978; Chandan et al., 2008). $24 \mathrm{~h}$ afterCCl${ }_{4}$ administration, all animals were 
euthanized and blood samples were collected from a common carotid into dry centrifuge tubes. Livers were then excised for tissue studies. The coagulated blood in the plain tubes were centrifuged and the serum was tested for liver markers including Total Protein (TP), Albumin (Alb), Globulin (Glob), bilirubin, Aspartate Aminotransferase (AST), Alanine Aminotransferase (ALT), Gamma Glutamyl Transferase (GGT) and Alkaline Phosphatase (ALP). Livers were preserved in $10 \%$ buffered (with $\mathrm{NaH}_{2} \mathrm{PO}_{4}$ ) formalin for histopathology studies.

\subsection{Curative Studies}

Six groups of rats $(A-F)(n=5)$ were used for the curative studies. Liver injury was induced by daily administration of $\mathrm{CCl}_{4}(20 \%$ in liquid paraffin; $1 \mathrm{~mL}$ $\mathrm{kg}^{-1}$ p.o) to groups (A-E) for five (5) consecutive days. Treatment was then initiated per gavage with Spathodea $\left(100,300,625, \mathrm{mg} \mathrm{kg}^{-1}\right)$, silymarin $\left(50 \mathrm{mg} \mathrm{kg}^{-1}\right)$ and vehicle (liquid paraffin, $1 \mathrm{~mL} \mathrm{~kg}^{-1}$ ) to the same groups of animals at 2,24 and $48 \mathrm{~h}$ after the last $\mathrm{CCl}_{4}$ administration (Chandan et al., 2008). Group F served as the normal control and so received only water throughout the experiment. Two (2) h after the last dose, all animals were euthanized and blood samples were collected from a common carotid into dry centrifuge tubes. Livers were then excised for tissue studies. The coagulated blood in the plain tubes were centrifuged and the serum was tested for liver markers including Total Protein (TP), Albumin (Alb), Globulin (Glob), bilirubin, Aspartate aminotransferase (AST), Alanine aminotransferase (ALT), Gamma Glutamyl Transferase (GGT) and Alkaline Phosphatase (ALP). Livers were preserved in $10 \%$ buffered (with $\mathrm{NaH}_{2} \mathrm{PO}_{4}$ ) formalin for histopathology studies and TBARS assay.

\subsection{Histopathology Studies}

Liver samples from both prophylactic and curative treatments for control and treated groups of animals were washed separately with normal saline. They were fixed in $10 \%$ buffered (with $\mathrm{NaH}_{2} \mathrm{PO}_{4}$ ) formalin for $24 \mathrm{~h}$ and used for the histology study. The method for processing was as reported by Galigher and Kozloff (1971). Briefly, livers were fixed for $12 \mathrm{~h}$ in Bouin's solution and processed for paraffin embedding using standard microtechniques. Sections of liver $(5 \mu \mathrm{m})$ stained with haematoxylin and eosin ( $\mathrm{H}$ and $\mathrm{E}$ ) were observed under light microscope for histopathological changes.

\subsection{Thiobarbituric Acid Reactive Substances (TBARS)}

Portions of livers blotted of blood were homogenized in phosphate buffered saline (1/10 weight/volume) and centrifuged at $10000 \mathrm{~g}$ for $10 \mathrm{~min}$ at $4^{\circ} \mathrm{C}$. Lipid peroxides (TBARS) in liver homogenate were estimated using thiobarbituric acid reactive substances (Ohkawa et al., 1979). Sodium Dodecyl Sulphate (SDS) $(0.2 \mathrm{~mL}$ of $8.1 \%), 1.5 \mathrm{~mL}$ of $20 \%$ Acetic acid and $1.5 \mathrm{~mL}$ of $0.8 \%$ TBA were added to $0.2 \mathrm{~mL}$ of tissue homogenate. The mixture was diluted to $4.0 \mathrm{~mL}$ with distilled water and heated in a water bath at $95^{\circ} \mathrm{C}$ for 60 min using a glass ball as a condenser. The mixture was left to cool after which $1.0 \mathrm{~mL}$ of water and $5.0 \mathrm{~mL}$ of $\mathrm{n}$-butanol/pyridine mixture were added and shaken vigorously. The tube with its content was then centrifuged at $4000 \mathrm{rpm}$ for 10 min. The organic layer was taken and its absorbance measured at $532 \mathrm{~nm}$ in a Shimadzu UV mini-1240, UVVIS Spectrophotometer. The procedure was repeated using 1, 1, 3, 3-tetramethoxypropane as standard. The level of lipid peroxidation was expressed as moles of TBA reactants/100 $\mathrm{g}$ of wet tissue.

\subsection{In Vitro Antioxidant Properties of Spathodea}

\subsubsection{Total Phenolic Content}

The entire soluble phenols present in the total crude extract $\left(0.1,0.3,1,3 \mathrm{mg} \mathrm{mL}^{-1}\right.$ in distilled water) was measured by colorimetric assay using the FolinCiocalteu's phenol reagent as described by Benklebia (2005) with some modifications using tannic acid (0.01, $0.03,0.1,0.3 \mathrm{mg} \mathrm{mL}^{-1}$ in distilled water) as standard. Four replicates each were used.

The test drug $(1 \mathrm{~mL})$ was added to $1 \mathrm{~mL}$ FolinCiocalteu's reagent (diluted tenfold in distilled water) in a test tube. The content of the test tube was mixed and allowed to stand for $5 \mathrm{~min}$ at $25^{\circ} \mathrm{C}$ in an incubator. 1.0 $\mathrm{mL}$ of $2 \%$ Sodium carbonate solution was added to the mixture. The reaction mixture was then allowed to stand for $2 \mathrm{~h}$ at $25^{\circ} \mathrm{C}$ in an incubator. It was then centrifuged at $3000 \mathrm{rpm}$ for $10 \mathrm{~min}$ to obtain a clear solution. The absorbance of the supernatant was determined at $760 \mathrm{~nm}$ using a Shimadzu 1240 UV-VIS Spectrophotometer (Shimadzu Scientific Instruments).

Distilled water $(1 \mathrm{~mL})$ was added to $1 \mathrm{~mL}$ FolinCiocalteu's reagent (diluted ten-fold in distilled water) and processed in the same way as the test drugs and used as control. A sample of only distilled water served as the blank. 


\subsection{Reducing Power}

The reducing power of the crude extract of Spathodea $\left(0.1,0.3,1,3 \mathrm{mg} \mathrm{mL}^{-1}\right)$ was determined by its ability to reduce $\mathrm{Fe}^{3+}$ to $\mathrm{Fe}^{2+}$ (Oyaizu, 1986) according to the method described in literature by Amarowicz et al. (2005) with modifications using tannic acid $(0.01,0.03$, $0.1,0.3 \mathrm{mg} \mathrm{mL}^{-1}$ ) as standard.

The method determines the ability of a test compound to reduce $\mathrm{Fe}^{3+}$ to $\mathrm{Fe}^{2+}$. The resultant $\mathrm{Fe}^{2+}$ then reacts with ferricyanide ion to form a Prussian blue complex with maximum absorbance at $700 \mathrm{~nm}$. The intensity of blue complex formed is directly proportional to the absorbance of the solution and reducing power of the test substance in solution:

$$
\begin{aligned}
& \mathrm{Fe}^{3+} \rightarrow \mathrm{Fe}^{2+} \\
& \mathrm{K} 3 \mathrm{Fe}(\mathrm{CN}) 6(\mathrm{aq})+\mathrm{Fe} 2+(\mathrm{aq}) \mathrm{KFe} \\
& {[\mathrm{Fe}(\mathrm{CN}) 6]+2 \mathrm{~K}+(\mathrm{aq})}
\end{aligned}
$$

The Tannic acid/extract solution $(1 \mathrm{~mL})$ was mixed with $2.5 \mathrm{~mL}$ of $0.2 \mathrm{M}$ sodium phosphate buffer ( $\mathrm{pH} 6.6$ ) and $2.5 \mathrm{~mL}$ of $1 \%$ potassium ferricyanide solution $\left[\mathrm{K}_{3} \mathrm{Fe}\right.$ $\left.(\mathrm{CN})_{6}(\mathrm{aq})\right]$ in a test tube. The mixture was incubated at $50^{\circ} \mathrm{C}$ for $20 \mathrm{~min}$. Trichloroacetic Acid solution (TCA) $(1.5 \mathrm{~mL}$ of $10 \%)$ was added to the incubated mixture and centrifuged at $3000 \mathrm{rpm}$ for $10 \mathrm{~min}$.

The supernatant $(2.5 \mathrm{~mL})$ was mixed with $2.5 \mathrm{~mL}$ distilled water and $0.5 \mathrm{~mL}$ of $0.1 \%$ ferric chloride solution $\left(\mathrm{FeCl}_{3}(\mathrm{aq})\right)$ in a test tube. The absorbance was then measured at $700 \mathrm{~nm}$ using Shimadzu $1240 \mathrm{UV}-\mathrm{VIS}$ spectrophotometer (Shimadzu Scientific Instruments).

Distilled water $(1 \mathrm{~mL})$ was added to $2.5 \mathrm{~mL}$ sodium phosphate buffer and $2.5 \mathrm{~mL}$ potassium ferricyanide $\left[\mathrm{K}_{3} \mathrm{Fe}(\mathrm{CN})_{6}\right]$ in a test tube. This mixture was taken through the same procedure as were the test drugs and used as blank. Six replicates were used.

\subsection{Effect of Spathodea on Total Cytochrome P450 Content}

SD rats weighing 150-200 $\mathrm{g}$ were used for the experiment. Animals were divided and housed in groups of five for 5 days before treatment.

Group A received distilled water and served as control. Groups B, C and D received SCE (625 mg kg-1), ketoconazole $\left(100 \mathrm{mg} \mathrm{kg}^{-1}\right)$ and phenobarbital $(100 \mathrm{mg}$ $\mathrm{kg}^{-1}$ ) respectively daily p.o for seven consecutive days. On the eighth day, the animals were euthanized. Livers were removed, blotted of blood and homogenized in a $0.25 \mathrm{M}$ sucrose solution at a ratio of $5 \mathrm{~mL} \mathrm{~g}^{-1}$ of tissue.
Phenyl Methane Sulphonyl Fluoride (PMSF) was added to inactivate serine proteases and the homogenate was centrifuged at $600 \mathrm{~g}$ for $5 \mathrm{~min}$. Supernatant was further centrifuged at $12000 \mathrm{~g}$ for $10 \mathrm{~min}$ and the subsequent supernatant further centrifuged at 100,000 g for $1 \mathrm{~h}$. The resultant pellets were suspended in $0.25 \mathrm{M}$ sucrose. Protein concentration was adjusted to $20 \mathrm{mg} \mathrm{mL}^{-1}$ using a modified Lowry method of protein assay. The cytochrome $\mathrm{P} 450$ level was then determined by forming the P450-carbon monoxide $(\mathrm{CO})$ complex, $\mathrm{CO}$, in a $\mathrm{CO}$ chamber leaving a non-CO complex control outside the chamber. The difference in absorbance at 450 and 490 was measured using a microplate reader.

P450 levels were calculated as:

$[\mathrm{P} 450](\mathrm{mM})=(\Delta \mathrm{Apc}-\Delta \mathrm{Ap}) / 91$

$\Delta \mathrm{Apc}=$ The change in absorbance of the $\mathrm{P} 450-\mathrm{CO}$ complex

$\Delta \mathrm{Ap}=$ The change in absorbance of the non-CO complex

\subsection{Statistical Analysis}

The results of hepatoprotective and antioxidant activities are expressed as mean \pm SEM. Results were statistically analysed using one-way ANOVA, followed by the Newman-Keuls Multiple Comparison Test. $\mathrm{p}<0.05$ were considered significant

\section{RESULTS}

\subsection{Effect of Spathodea on $\mathrm{CCl}_{4}$ Induced Hepatotoxicity}

\subsubsection{Prophylactic Studies}

\subsubsection{Effect on Serum Enzymes}

The effect of pre-treatment with Spathodea campanulata and silymarin on serum enzymes of $\mathrm{CCl}_{4}$ intoxicated rats is shown in Table 1. The administration of a single dose of $\mathrm{CCl}_{4}$ significantly increased the levels of AST $(p<0.01)$ and ALT $(p<0.001)$, compared to the untreated control. In the groups pre-treated with different doses of Spathodea or silymarin before $\mathrm{CCl}_{4}$ intoxication, AST and ALT reduced significantly compared to the $\mathrm{CCl}_{4}$-only treated group. Spathodea at $625 \mathrm{mg} \mathrm{kg}^{-1}$ also reversed the elevated GGT induced by $\mathrm{CCl}_{4}$ treatment to normal levels (Table 1). Doses of Spathodea less than $625 \mathrm{mg} \mathrm{kg}^{-1}$ did not have any significant effect in protecting the liver from the impending hepatotoxicity from $\mathrm{CCl}_{4}$ (results not shown). 
Charles Ansah et al. / American Journal of Pharmacology and Toxicology 8 (1): 39-50, 2013

Table 1. Effect of Spathodea campanulata on some biochemical parameters of rats treated with extracts and silymarin before $\mathrm{CCl}_{4}$ intoxication (prophylactic). Values are presented as the mean \pm SEM $(\mathrm{n}=5)$.***/+++ indicates $(\mathrm{p}<0.001), * * /++$ indicates $(\mathrm{p}<0.01) . * /+$ indicates $(\mathrm{p}<0.05)$ compared to the control by Newman Keuls test. (+ significant compared to vehicle control; * significant compared to toxin control)

\begin{tabular}{lcccccc}
\hline & & & SCE & & & \\
Parameter & Vehicle control & $\mathrm{CCl}_{4}$ control & $625 \mathrm{mg} \mathrm{kg}^{-1}$ & $1250 \mathrm{mg} \mathrm{kg}^{-1}$ & $2500 \mathrm{mg} \mathrm{kg}^{-1}$ & $\begin{array}{l}\text { Silymarin } \\
\left(50 \mathrm{mg} \mathrm{kg}^{-1}\right)\end{array}$ \\
\hline AST & $163.2 \pm 12.58$ & $452.3 \pm 29.85++$ & $243.2 \pm 54.03$ & $368.4 \pm 41.51$ & $371.0 \pm 59.41$ & $328.0 \pm 5.38$ \\
ALT & $65.20 \pm 5.928$ & $823.5 \pm 62.28+++$ & $391.8 \pm 69.77 *$ & $551.8 \pm 139.1$ & $578.4 \pm 131.3$ & $378.8 \pm 107.2^{*}$ \\
T. BIL & $4.560 \pm 0.3982$ & $4.80 \pm 0.5788$ & $4.640 \pm 0.2619$ & $5.00 \pm 0.1871$ & $5.060 \pm 0.3108$ & $4.640 \pm 0.4925$ \\
ALBUMIN & $4.760 \pm 0.1166$ & $4.673 \pm 0.0250$ & $4.400 \pm 0.07071$ & $4.440 \pm 0.1208$ & $4.680 \pm 0.05831$ & $4.480 \pm 0.0800$ \\
GGT & $3.600 \pm 1.288$ & $7.250 \pm 1.315$ & $2.600 \pm 0.8124^{*}$ & $5.400 \pm 0.9274$ & $3.400 \pm 0.6782$ & $4.200 \pm 0.4899$ \\
ALP & $278.4 \pm 9.244$ & $463.5 \pm 12.69$ & $403.0 \pm 22.03$ & $470.8 \pm 125.0$ & $389.8 \pm 29.35$ & $454.0 \pm 83.77$ \\
PRO & $8.300 \pm 0.7616$ & $9.500 \pm 0.1683$ & $9.280 \pm 0.08602$ & $8.940 \pm 0.2379$ & $9.620 \pm 0.1281$ & $9.200 \pm 0.1761$ \\
\hline AST & A & & &
\end{tabular}

AST $=$ Aspartate Amino Transferase, ALT $=$ Alanine Amino Transferase, T.BIL $=$ Total biliRubin, GGT = Gamma Glutamyl

Transpeptidase, $\mathrm{ALP}=$ Alkaline phoSphatase, $\mathrm{PRO}=$ Total Protein

\subsection{Histopathological Examination of the livers of Rats Pre-Treated with Spathodea and Silymarin before $\mathrm{CCl}_{4}$ Treatment}

Liver sections taken from untreated $\mathrm{CCl}_{4}$-injured rats had profound inflammatory infiltration, hepatocyte coagulative necrosis and fibrous septa compared to that from the healthy control group (Fig. 1). Qualitative and quantitative histological analysis showed that silymarin and Spathodea $\left(625 \mathrm{mg} \mathrm{kg}^{-1}\right)$ markedly improved the degree of hepatic fibrosis in $\mathrm{CCl}_{4}$-injured rats. Treated groups displayed delicate fibrous septa and lower collagen levels than untreated $\mathrm{CCl}_{4}$-injured group. There was mild cellular degeneration, necrosis and inflammation in the group treated with $625 \mathrm{mg} \mathrm{kg}^{-1}$ Spathodea. Animals treated with $1250 \mathrm{mg}$ also showed mild cellular degeneration, necrosis and inflammation. The silymarin $(50 \mathrm{mg}$ $\mathrm{kg}^{-1}$ ) group suffered mild inflammation and cellular degeneration with very mild necrosis. In the $\mathrm{CCl}_{4}$ control group, there was moderate cellular degeneration and necrosis, inflammation and fibrosis than in all the treatment groups.

\subsection{Curative Studies}

\subsubsection{Effect on Serum Markers}

The effect of Spathodea in modulating $\mathrm{CCl}_{4}$ induced hepatotoxicity is shown in Table 2. The administration of Spathodea and silymarin significantly reduced the AST, ALT and total bilirubin induced by $\mathrm{CCl}_{4}$ compared to the normal control by Newman Keul's test. The decrease was profound at lower doses. The extract and silymarin however did not significantly decrease the elevated Blood Urea Nitrogen (BUN) (Table 2). GGT and total proteins were not significantly affected by the toxin.

\subsection{Histopathology Studies}

Liver sections from $\mathrm{CCl}_{4}$-injured rats had more inflammatory infiltration, steatosis and coagulative necrosis than healthy control group (Fig. 2). The extract at 100 and $300 \mathrm{mg} \mathrm{kg}^{-1}$ respectively did not show significant improvement over the effect of $\mathrm{CCl}_{4}$ on the liver. Though the extent of steatosis improved in the Spathodea-treated group especially at the $625 \mathrm{mg} \mathrm{kg}^{-1}$ dose, liver architecture (coagulative necrosis) did not change. Similarly, cellular degeneration, necrosis and inflammation were mild in the $625 \mathrm{mg} \mathrm{kg}^{-1}$ treated group. The standard drug (silymarin) treated group also showed considerable improvement in fatty infiltration.

\subsection{Lipid Peroxidation}

TBA reactive substance level (Fig. 3) increased significantly in the carbon tetrachloride treated animals relative to the control to nearly six fold $(\mathrm{p}<0.001)$. The increase was reversed to near normal with Spathodea at all doses compared to the control $(\mathrm{p}<0.001)$.

\subsection{In vitro Antioxidant Properties of Spathodea}

\subsubsection{Total Phenolic Content}

The total phenol content of tannic acid (0.01- $0.3 \mathrm{mg}$ $\left.\mathrm{mL}^{-1}\right)$ expressed as absorbance increased with increasing concentration $\left(r^{2}=0.97\right)$ (Fig. 4). Spathodea (0.1-3.0 $\mathrm{mg} \mathrm{mL} \mathrm{m}^{-1}$ ) also showed a dose dependent increase in phenolic content $(0.0009 \pm 0.00006$ to $0.0856 \pm 0.0012)$ expressed as tannic acid equivalent. The content of total phenols in the extract was however found to be lower than that of the tannic acid. 
Charles Ansah et al. / American Journal of Pharmacology and Toxicology 8 (1): 39-50, 2013

Table 2. Effect of Spathodea campanulata and Silymarin on biochemical parameters of rats treated with $\mathrm{CCl}_{4}$ (curative). Values are expressed as means \pm SEM $(\mathrm{n}=5)$, *** indicates significance $(\mathrm{p}<0.001)$ and $* *$ indicates $(\mathrm{p}<0.01)$. ( Significant compared to normal control, *Significant compared to toxin control)

\begin{tabular}{|c|c|c|c|c|c|c|}
\hline \multirow[b]{2}{*}{ Parameter } & \multirow[b]{2}{*}{ Normal control } & \multirow[b]{2}{*}{$\mathrm{CCl}_{4}$ control } & \multicolumn{3}{|l|}{ SCE } & \multirow{2}{*}{$\begin{array}{l}\text { Silymarin } \\
\left(50 \mathrm{mg} \mathrm{kg}^{-1}\right)\end{array}$} \\
\hline & & & $100 \mathrm{mg} \mathrm{kg}^{-1} \mathrm{SCE}$ & $300 \mathrm{mg} \mathrm{kg}^{-1} \mathrm{SCE}$ & $625 \mathrm{mg} \mathrm{kg}^{-1} \mathrm{SCE}$ & \\
\hline AST & $214.5 \pm 17.27$ & $592.5 \pm 120.0+++$ & $235.3 \pm 19.03^{* *}$ & $266.9 \pm 13.06^{* *}$ & $437.9 \pm 20.94$ & $382.8 \pm 17.24 *$ \\
\hline ALT & $133.5 \pm 9.441$ & $577.0 \pm 161.9++$ & $190.5 \pm 15.25 * *$ & $202.3 \pm 26.88^{* *}$ & $295.7 \pm 22.51^{*}$ & $278.9 \pm 13.57 *$ \\
\hline Total Protein & $61.80 \pm .235$ & $66.96 \pm 1.739$ & $60.64 \pm 2.179$ & $61.58 \pm 2.127$ & $77.62 \pm 1.573$ & $72.34 \pm 1.725$ \\
\hline Total Bilirubin & $1.50 \pm 0.100$ & $3.740 \pm 0.419+++$ & $1.660 \pm 0.093 * * *$ & $2.220 \pm 0.2518 * *$ & $3.620 \pm 0.447$ & $2.420 \pm 0.153 * *$ \\
\hline BUN & $5.222 \pm 0.2217$ & $10.42 \pm 0.425+++$ & $7.646 \pm 0.558$ & $11.52 \pm 1.423$ & $9.266 \pm 0.503$ & $8.752 \pm 0.769$ \\
\hline GGT & $0.0 \pm 0.0$ & $1.960 \pm 0.625$ & $1.940 \pm 1.018$ & $1.940 \pm 0.498$ & $2.920 \pm 1.058$ & $2.540 \pm 1.364$ \\
\hline
\end{tabular}

AST $=$ Aspartate Amino Transferase, ALT = Alanine Amino Transferase, BUN = Blood Urea Nitrogen, GGT = Gamma Glutamyl Transpeptidase

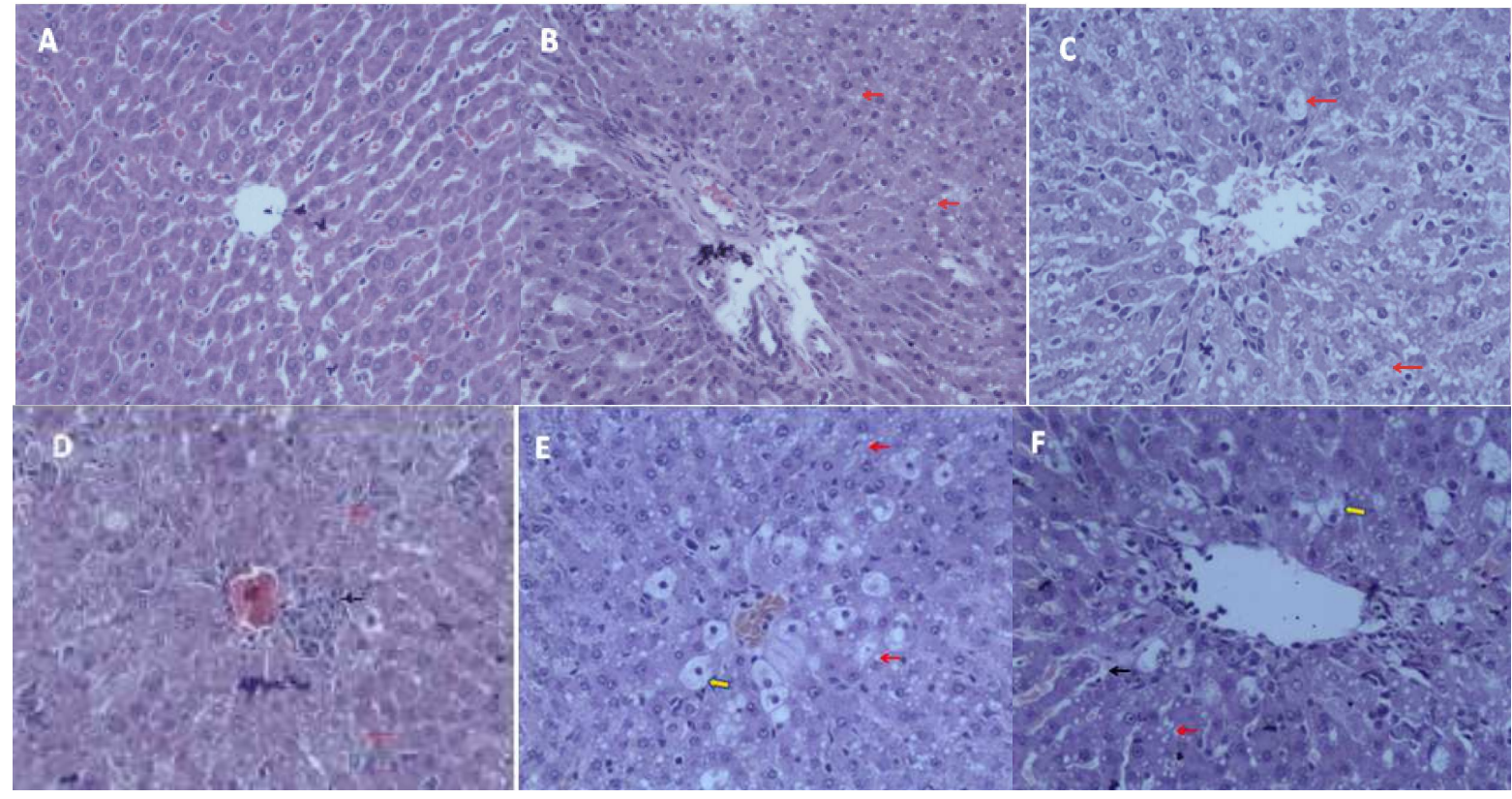

Fig. 1. Photomicrograph $(\times 400)$ showing histopathological profile of the livers of rats in SCE prophylactic treatment. Sections of the liver after treatment with Spathodea campanulata stem bark extract/Silymarin before $\mathrm{CCl}_{4}$ intoxication. (A) Normal Control, liver from rat treated with saline shows normal cellular architecture with distinct hepatic cells, (B) $625 \mathrm{mg} \mathrm{kg}^{-1}$, (C) $1250 \mathrm{mg}$ $\mathrm{kg}^{-1}$, (D) $2500 \mathrm{mg} \mathrm{kg}^{-1}$, (E) Silymarin, (F) $\mathrm{CCl}_{4}$ Control. $(\rightarrow)$ Indicates macrovesicular steatosis, $(\rightarrow$ ) indicates steatosis (fatty liver), $(\rightarrow)$ indicates fibrous septa

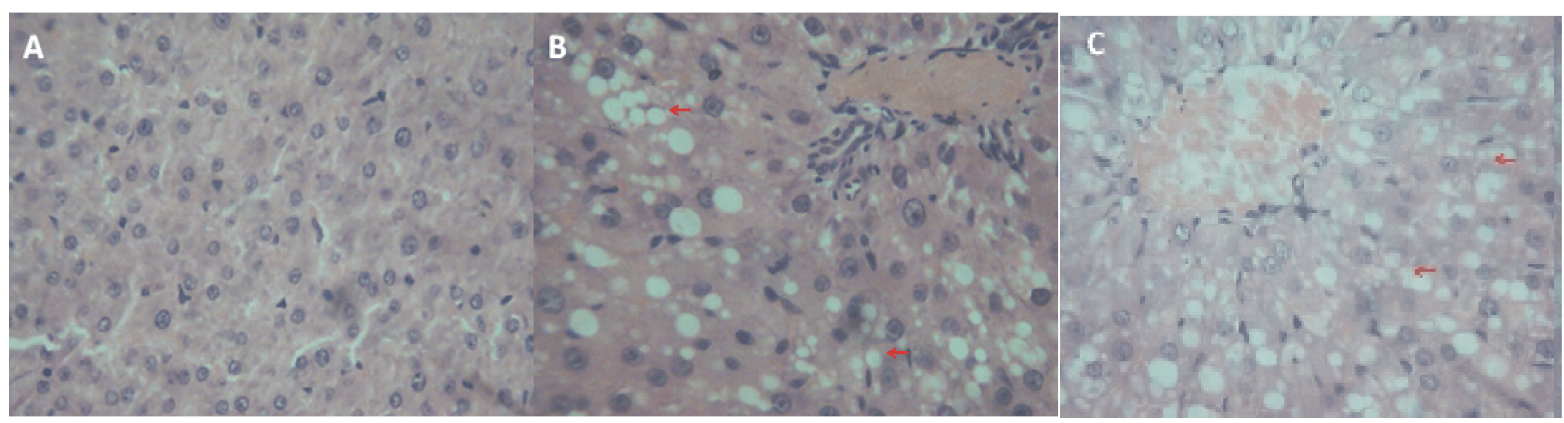



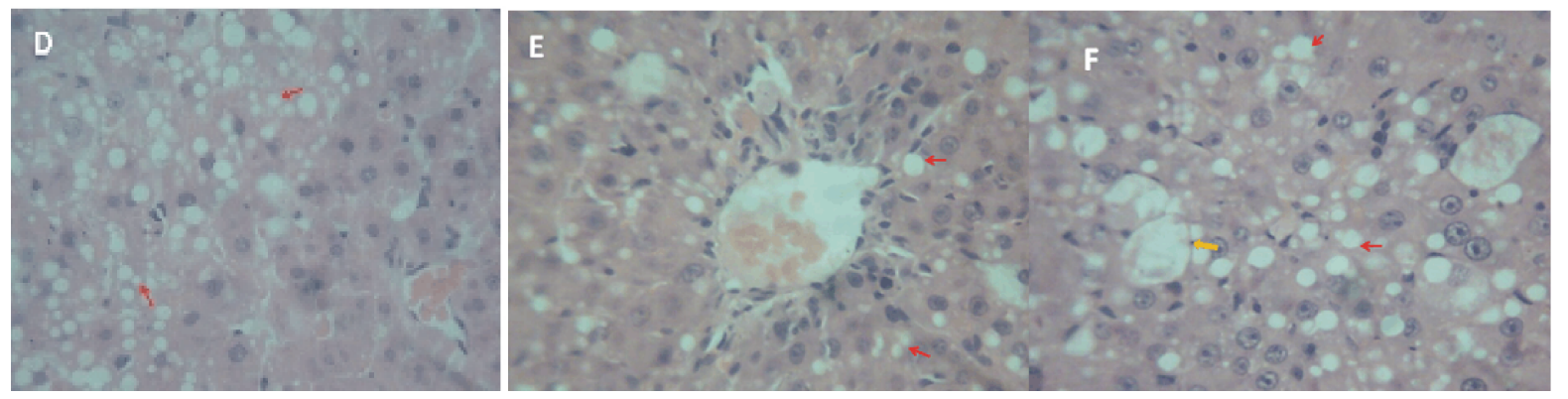

Fig. 2. Photomicrograph $(\times 400)$ showing histopathological profile of the livers of rats treated with $\mathrm{CCl}_{4}$ followed by SCE treatment (curative treatment)

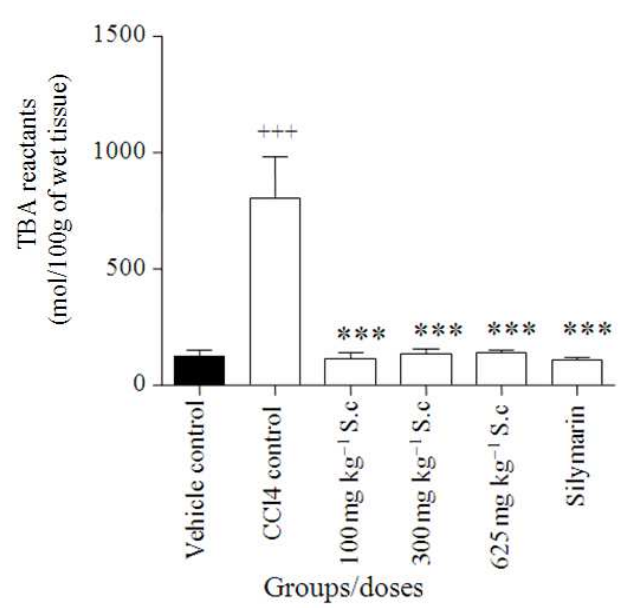

Fig. 3. Changes in TBARS level in normal and experimental rats. Values represent mean \pm SEM for five animals in each group. Values are statistically significant at +++ $\mathrm{p}<0.001$ when compared with the vehicle control and $* * * \mathrm{p}<0.001$ when compared with the toxin control

\subsection{Reducing Power}

The extract at $0.1-3 \mathrm{mg} \mathrm{mL} L^{-1}$ and the standard antioxidant Tannic acid at $0.01-0.3 \mathrm{mg} \mathrm{mL}^{-1}$ dose dependently reduced $\mathrm{Fe}^{3+}$ to $\mathrm{Fe}^{2+}$ resulting in dose dependent increase in absorbance (Fig. 5). The EC50 showed that the extract (with EC50 of $1071 \mathrm{mg} \mathrm{mL}^{-1}$ ) is approximately 100 fold less potent than the standard drug Tannic acid (EC50 of $10.87 \mathrm{mg} \mathrm{mL}^{-1}$ ).

\subsection{Effect on Total Cytochrome P450}

Treatment of rats with Spathodea resulted in a profound decrease in the total cytochrome P450 enzyme content in the liver (Fig. 6). The decrease was comparable to ketoconazole a known inhibitor of cytochrome P450. Phenobarbital (an inducer) increased the total cytochrome P450 enzymes compared to the control.

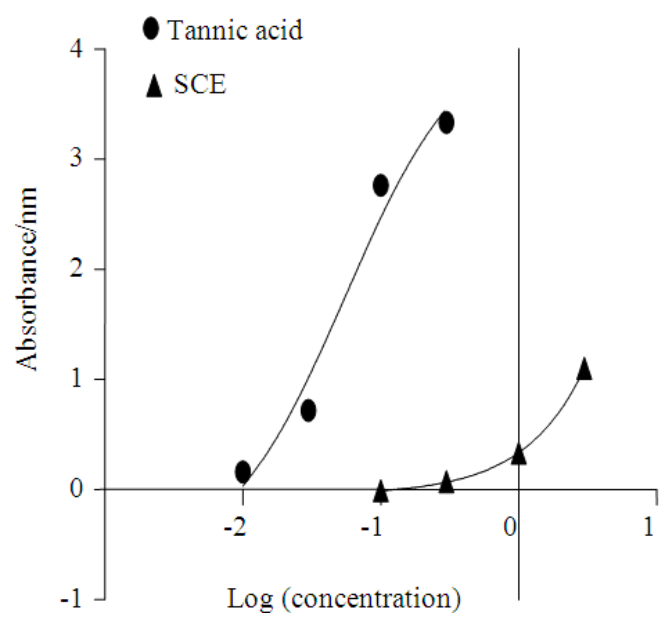

(a)

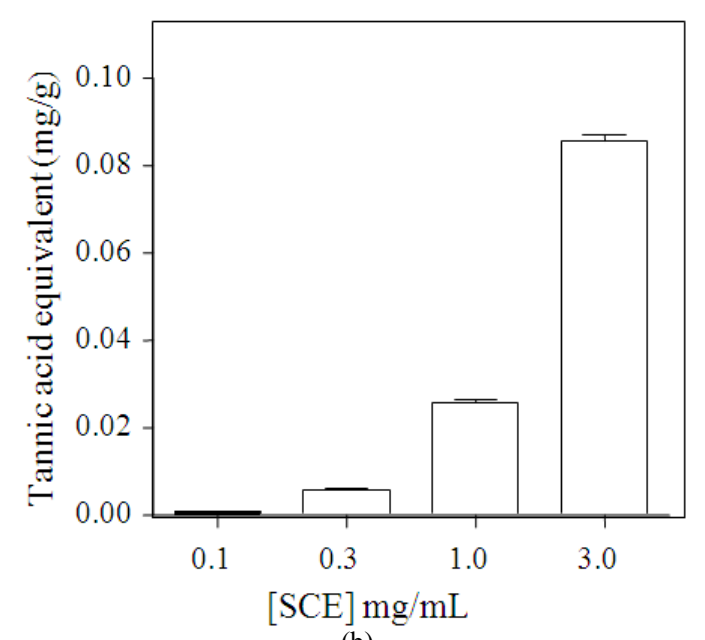

(b)

Fig. 4. (a) Log (concentration) against absorbance of tannic acid and SCE and (b) Total phenolic content of SCE (0.1-3.0 $\left.\mathrm{mg} \mathrm{kg}^{-1}\right)$ expressed as tannic acid equivalent $(\mathrm{mg} / \mathrm{g}$ extract). Each point represents the mean $\pm \operatorname{SEM}(n=4)$ 


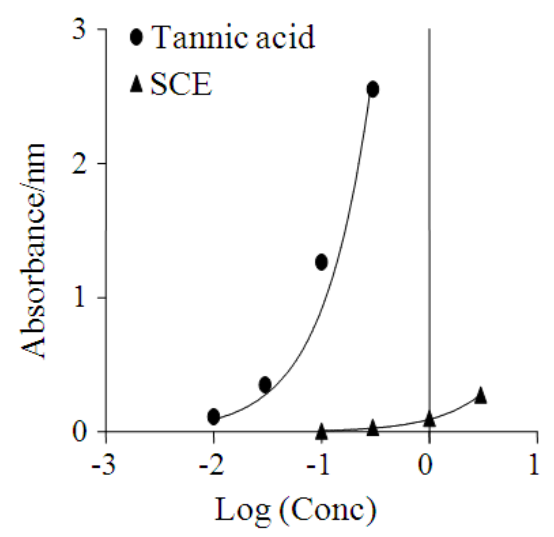

Fig. 5. Reducing power of SCE $\left(0.1-3.0 \mathrm{mg} \mathrm{kg}^{-1}\right)$ compared with tannic acid $\left(0.01-0.3 \mathrm{mg} \mathrm{kg} \mathrm{kg}^{-1}\right)$. Each point represent the mean $\pm \operatorname{SEM}(\mathrm{n}=3)$

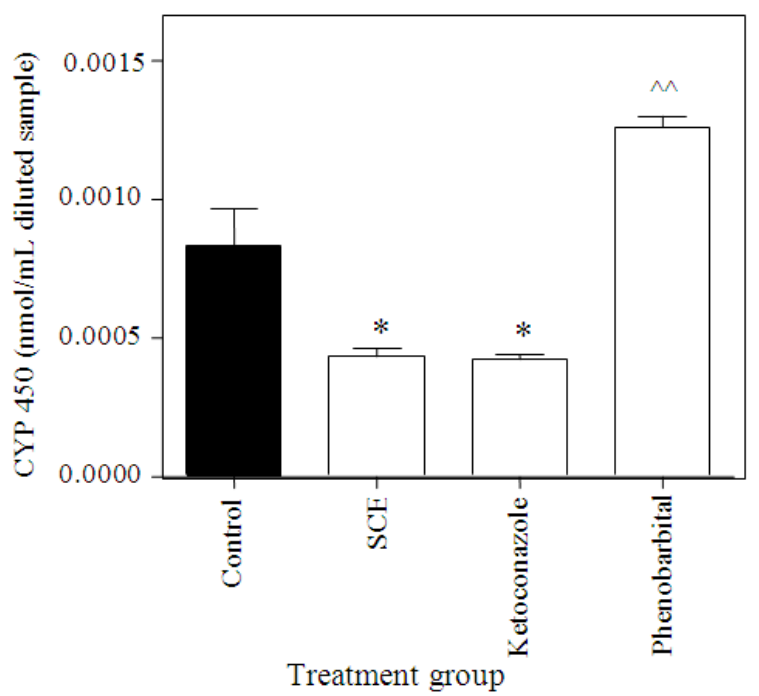

Fig. 6. Effect of SCE treatment on total liver cytochrome P450 content in rats. Values are presented as the mean \pm SEM $(n=5) . *$ indicates significant decrease $(\mathrm{p}<0.05)$ compared to the control; and $\wedge$ indicates significant increase $(\mathrm{p}<0.01)$ compared to the control

\section{DISCUSSION}

The liver is a multipurpose organ in the body involved in the breakdown of toxins in the body. Damage to the liver inflicted by hepatotoxic agents is therefore of critical consequence. The changes associated with $\mathrm{CCl}_{4}$-induced liver damage are comparable to that of acute viral hepatitis (Rubinstein, 1962), consequently $\mathrm{CCl}_{4}$-mediated hepatotoxicity was employed as the experimental model for liver injury. The $\mathrm{CCl}_{4}$ model for hepatotoxicity has been extensively studied. It is now established that $\mathrm{CCl}_{4}$ accumulates in hepatic parenchymal cells and is metabolically activated by cytochrome $\mathrm{P}-450$ dependent monooxygenases to form a trichloromethyl free radical $\left(\mathrm{CC}_{3}{ }^{\prime}\right)$. This radical alkylates cellular proteins (including cytochrome P450) and other macromolecules (Bishayee et al., 1995) with a concurrent attack on polyunsaturated fatty acids in the presence of oxygen to generate lipid peroxides (Bishayee et al., 1995; Recknagel, 1983) leading to liver damage.

For many years now, hepatotoxic compounds such as $\mathrm{CCl}_{4}$ have been known to cause marked elevation in serum transaminases.

In agreement with results obtained in similar investigations (Bishayee et al., 1995), $\mathrm{CCl}_{4}$ in the present study elicited a significant increase in the levels of serum transaminases (ALT, AST and GGT). This was evident in both prophylactic and curative studies.

Administration of the extract to rats before intoxication was to determine if the extract has the ability to condition the hepatocytes to promote accelerated regeneration of parenchymal cells, thus protecting against membrane fragility and decreasing the leakage of marker enzymes into the circulation in the event of $\mathrm{CCl}_{4}$ intoxication.

The increase in ALT in the $\mathrm{CCl}_{4}$ group (in the prophylactic studies) was about thirteen fold that of the control whereas AST increased about three fold in the $\mathrm{CCl}_{4}$ group compared to the control. The two enzymes most often associated with hepatocellular damage are AST and ALT. ALT is specifically produced in the hepatocytes, making it relatively a better determinant of hepatic injury as opposed to the AST, which is observed in higher levels in a variety of tissues such as liver, muscle and red blood cells. Consequently, muscle injury/trauma (intra muscular injections, severe restraint during handling) and haemolysis can lead to significant AST elevations (Ramaiah, 2007). Again, AST has a shorter half-life of about $12 \mathrm{~h}$ whiles ALT has a half-life of about $60 \mathrm{~h}$ (Meyer and Harvey, 2004). The lowest dose (prophylactic studies), $625 \mathrm{mg} \mathrm{kg}^{-1}$, significantly decreased the elevated ALT, AST and GGT, but not higher doses. Lower doses than $625 \mathrm{mg} \mathrm{kg}^{-1}$ (100 and 300) had no effect on the liver prophylactically. Silymarin in all cases decreased the degree of toxicity, which was comparable to the Spathodea extract. 
The liver has the capacity to regenerate when left alone after intoxication especially in acute toxicity (Timbrel, 2009) consequently, the rats were given five doses to ensure that toxicity to the liver is sustained before treatment was commenced. There was considerable increase in the AST and ALT in the curative study by $\mathrm{CCl}_{4}$. The $625 \mathrm{mg} \mathrm{kg}^{-1}$ of the extract and silymarin $\left(50 \mathrm{mg} \mathrm{kg}^{-1}\right)$ reduced AST and ALT levels significantly, confirming the efficacy of lower doses of the extract as in the prophylactic study. Although ALT is markedly more specific for liver function as stated earlier, nevertheless serum levels of AST and ALT rise and fall in parallel (Rose et al., 2007).

Gamma Glutamyl Transferase (GGT) level was raised after the administration of $\mathrm{CCl}_{4}$ in the prophylactic treatment but was unaffected in the curative study. GGT and ALP are employed to detect impaired bile flow (cholestasis). Impaired bile flow caused by drugs and other toxins evoke increased synthesis of these enzymes within hours, which are released into the circulation by unknown mechanisms (Ramaiah, 2007).

Total serum bilirubin can also be employed to detect cholestasis in addition to the GGT and ALP as well as in hepatocellular damage (Ramaiah, 2007). Unlike the prophylactic studies, total bilirubin levels in the serum of the rats increased significantly in the toxin control in the curative studies. This increase was reduced to normal levels by doses of 100 and $300 \mathrm{mg} \mathrm{kg}^{-1}$ of extract as well as silymarin.

The administration of $\mathrm{CCl}_{4}$ did not affect the serum total protein levels in both the prophylactic and curative studies. Between one and $3 \mathrm{~h}$ after dosing with carbon tetrachloride, triglycerides accumulate in hepatocytes, detectable as fat droplets and there is continued loss of enzyme activity in the endoplasmic reticulum (Timbrel, 2009). As expected, liver sections from untreated $\mathrm{CCl}_{4}$ injured rats had higher degree of inflammation and fibrous septa than the treated groups. Rats that received 625 and $1250 \mathrm{mg} \mathrm{kg}^{-1}$, in the prophylactic studies, showed mild cellular degeneration, necrosis and inflammation. In the highest dose however, cellular degeneration was more pronounced comparable to the untreated $\mathrm{CCl}_{4}$ group with mild necrosis and fibrosis. It is possible that at high doses of the extract, the effect of some components of the extract with potential toxicity become more pronounced. The silymarin treated animals showed very mild inflammation and cellular degeneration and fibrosis. Extract treated groups showed delicate fibrous septa and lower collagen levels than untreated $\mathrm{CCl}_{4}$-injured rats.
Light microscopic studies confirmed the curative potential of Spathodea against $\mathrm{CCl}_{4}$ induced liver damage as evident by the reversal of centrilobular necrosis, macrovesicular fatty changes (steatosis) and inflammation in hepatic parenchyma after $\mathrm{CCl}_{4}$ administration.

$\mathrm{CCl}_{4}$ intoxication in various studies has demonstrated that $\mathrm{CCl}_{4}$ causes free radical generation in many tissues such as liver, kidney, brain, heart lung and blood (Ganie et al., 2011). Carbon tetrachloride $\left(\mathrm{CCl}_{4}\right)$ is biotransformed by the cytochrome $\mathrm{P} 450$ enzymes to the trichloromethyl $\left(\mathrm{CCl}_{3}{ }^{\prime}\right)$ radical, a hepatotoxic metabolite. Covalent binding of this radical to proteins initiates a cascade of events leading to cell necrosis.

Antioxidants have been shown to protect cellular DNA against oxidative stress by reducing the level of free radicals in the cells and increasing the level of typical antioxidant enzymes (Awad et al., 2008). Indeed the elevation in the levels of the end products of lipid peroxidation (MDA) in $\mathrm{CCl}_{4}$-treated rat livers was reversed by treatment with the extract. The increase in MDA levels in the liver implied enhanced peroxidation leading to tissue damage and malfunction of the antioxidant defence mechanisms (Naik and Panda, 2007).

Among the many drugs for liver injury, silymarin is the most clinically popular and is known to have hepatotherapeutic and anti-fibrotic properties (Kim et al., 2007). Silymarin has also shown effectiveness in several studies, such as protection against genomic injury and increasing hepatocyte protein synthesis. It is also known to prevent lipid peroxidation in some experimental models (Soto et al., 1998). Some authors are however of the view it has a low bioavailability (Comoglio et al., 1995; Giacomelli et al., 2002). The present results suggest that the mechanism of hepatoprotection of Spathodea may at least in part be due to its antioxidant properties evidenced by the ability to reduce lipid peroxidation in $\mathrm{CCl}_{4}$ injured rats. The reducing power and total phenolic content which were tested in the in vitro antioxidant experimental models further supports this assertion. An examination of whether SCE can reduce $\mathrm{Fe}^{3+}$ to $\mathrm{Fe}^{2+}$ gave a positive result. The reduction of $\mathrm{Fe}^{3+}$ to $\mathrm{Fe}^{2+}$ is a property of antioxidants. They are able to donate electrons to reactive radicals converting them into more stable and unreactive species (Cetinkaya et al., 2011). This is the reducing power of the antioxidant. The extract also has an appreciable level of phenolic compounds according to the total phenolic test. Phytochemicals such as flavonoids and other polyphenol constituents of plants have been 
reported to be effective radical scavengers and inhibitors of lipid peroxidation (Dai and Mumper, 2010; Ebrahimzadeh et al., 2010). Phenolic compounds are the most wide spread secondary metabolites in the plant kingdom. These diverse groups of compounds have received much attention as potential natural antioxidants in terms of their ability to act as both efficient radical scavengers and metal chelators. It is reported that the antioxidant activity of phenols is largely due to their redox properties, hydrogen donors and singlet oxygen quenchers (Rice-Evans et al., 1995). The presence of phenols together with the reducing ability of the extract in addition to the DPPH scavenging activity (Houghton et al., 2005) shows that SCE has antioxidant properties which may be responsible for its hepatoprotective activity.

In addition, the inhibition of cytochrome P450 by the extract could play an important role in prevention of hepatotoxicity. Since carbon tetrachloride has to be activated by CYP 450 to tri-chloro methyl radical before the hepatotoxic effect can be exerted, inhibition in the activity of CYP450, a property of SCE, can therefore decrease the susceptibility of the liver to hepatic injury from $\mathrm{CCl}_{4}$.

\section{CONCLUSION}

This study has demonstrated that the aqueous stem bark extract of Spathodea campanulata has the capacity to modulate carbon tetrachloride induced hepatic damage in rats. The study further suggests that the protective activity of the extract is linked to its antioxidant activity and inhibition of CYP450, the enzymes involved in the bioactivation of $\mathrm{CCl}_{4}$.

\section{ACKNOWLEDGEMENT}

The researchers are very grateful to Mr. Thomas Ansah of the Department of Pharmacology, KNUST for his technical support.

\section{REFERENCES}

Abbiw, D.K., 1990. Useful plants of Ghana: West African Uses of Wild and Cultivated Plants. 1st Edn., Intermediate Technology Publications, Kew, ISBN-10: 1853390437, pp: 337.

Amarowicz, R., A. Troszynska and F. Shahidi, 2005. Antioxidant activity of almond seed extract and its fractions. J. Food Lipids, 12: 344-358. DOI: 10.1111/j.1745-4522.2005.00029.x
Awad, A.B., S.L. Barta, C.S. Fink and P.G. Bradford, 2008. $\beta$-Sitosterol enhances tamoxifen effectiveness on breast cancer cells by affecting ceramide metabolism. Mol. Nut. Food Res., 52: 419-426. DOI: $10.1002 / \mathrm{mnfr} .200700222$

Benklebia, N., 2005. Free-radical scavenging capacity and antioxidant properties of some selected onions (Allium cepa L.) and Garlic (Allium sativum L.) extracts. Brazilian Arch. Biol. Technol., 48: 753-759. DOI: 10.1590/S151689132005000600011

Bishayee, A., A. Sarkar and M. Chatterjee, 1995. Hepatoprotective activity of carrot (Daucus carota L.) against carbon tetrachloride intoxication in mouse liver. J. Ethnopharmacol., 47: 69-74. DOI: 10.1016/0378-8741(95)01254-B

Bremanti, G., W. Murmann, P. Pierini and M. Comporti, 1978. Effect of cicloxilic acid on CCl4-induced liver injury. Arzneimittel Forschung, 28: 1212-1217. DOI: 10.1016/0378-8741(95)01254-B

Cetinkaya, Y., H. Gocer, A. Menzek and I. Gulcin, 2011. Synthesis and antioxidant properties of $(3,4-$ Dihydroxyphenyl)(2,3,4-

trihydroxyphenyl)methanone and its derivatives. Archiv der Pharmazie (Weinheim), 345: 323-334. DOI: $10.1002 / \operatorname{ardp} .201100272$

Chandan, B.K., A.K. Saxena, S. Shukla, N. Sharma and D.K. Gupta et al., 2008. Hepatoprotective activity of Woodfordia fruticosa Kurz flowers against carbon tetrachloride induced hepatotoxicity. J. Ethnopharmacol., 119: 218-224. DOI: 10.1016/j.jep.2008.06.020

Comoglio, A., A. Tomasi, S. Malandrino, G. Poli and E. Albano, 1995. Scavenging effect of silipide, a new silybin-phospholipid complex, on ethanol-derived free radicals. Biochem. Pharmacol., 50: 1313-1316. DOI: 10.1016/0006-2952(95)02001-S

Dai, J. and R.J. Mumper, 2010. Plant phenolics: Extraction, analysis and their antioxidant and anticancer properties. Molecules, 15: 7313-7352. DOI: 10.3390/molecules15107313

Ebrahimzadeh, M.A., S.M. Nabavi, S.F. Nabavi, F. Bahramian and A.R. Bekhradnia, 2010. Antioxidant and free radical scavenging activity of $H$. officinalis L. var. angustifolius, $V$. odorata, $B$. hyrcana and C. speciosum. Pak. J. Sci., 23: 29-34. PMID: 20067863 
Galigher, A.E. and E.N. Kozloff, 1971. Essentials of practical Microtechnique. 2nd Edn., Lea and Febiger, Philadelphia, pp: 531.

Ganie, S.A., E. Haq, A. Hamid, Y. Qurishi and Z. Mahmood et al., 2011. Carbon tetrachloride induced kidney and lung tissue damages and antioxidant activities of the aqueous rhizome extract of podophyllum hexandrum. BMC Complementary Alternative Med., 11: 17-17. DOI: 10.1186/14726882-11-17

Giacomelli, S., D. Gallo, P. Apollonio, C. Ferlini and M. Distefano et al., 2002. Silybin and its bioavailable phospholipid complex (IdB 1016) potentiate in vitro and in vivo the activity of cisplatin. Life Sci., 70: 1447-1459. DOI: 10.1016/S0024-3205(01)01511-9

Houghton, P.J., P.J. Hylands, A.Y. Mensah, A. Hensel and A.M. Deters, 2005. In vitro tests and ethnopharmacological investigations: Wound healing as an example. J. Ethnopharmacol., 100: 100-107. DOI: 10.1016/j.jep.2005.07.001

Joly, A.B., 1985. Introduction to taxonomic vegetation.

Kim, E.Y., E.K. Kim, H.S. Lee, Y. Sohn and Y. Soh et al., 2007. Protective effects of cuscutae semen against dimethylnitrosamine-induced acute liver injury in sprague-dawley rats. Biol. Pharmaceutical Bull., 30: 1427-1431. DOI: 10.1248/bpb.30.1427

Lieber, C.S., M.A. Leo, Q. Cao, C. Ren and L.M. Decarli, 2003. Silymarin retards the progression of alcohol-induced hepatic fibrosis in baboons. J. Clin. Gastroenterol., 37: 336-339. DOI: 10.1097/00004836-200310000-00013

Makinde, J.M., O.O.G. Amusan and E.K. Adesogan, 1988. The antimalarial activity of Spathodea campanulata stem bark extract on Plasmodium berghei berghei in mice. Planta Med., 54: 122-125. DOI: $10.1055 / \mathrm{s}-2006-962367$

Mbosso, E.J.T., S. Ngouela, J.C.S. Nguedia, V.P. Beng and M. Rohmer et al., 2008. Spathoside, a cerebroside and other antibacterial constituents of the stem bark of Spathodea campanulata. Natural Product. Res., 22: 296-304. DOI: 10.1080/14786410701766281

Mensah, A.Y., P.J. Houghton, R.A. Dickson, T.C. Fleischer and M. Heinrich et al., 2006. In vitro evaluation of effects of two Ghanaian plants relevant to wound healing. Phytotherapy Res., 20: 941-944. DOI: $10.1002 /$ ptr. 1978
Meyer, D. and J.W. Harvey, 2004. Hepatobiliary and Skeletal Muscle Enzymes and Liver Function Tests. In: Veterinary Laboratory Medicine: Interpretation and Diagnosis, Meyer, D.J. and J.W. Harvey (Eds.), WB.Saunders, St. Louis, ISBN-10: 0721689264, pp: 169-192.

Naik, S.R. and V.S. Panda, 2007. Antioxidant and hepatoprotective effects of Ginkgo biloba phytosomes in carbon tetrachloride-induced liver injury in rodents. Liver Int., 27: 393-399. DOI: 10.1111/j.1478-3231.2007.01463.x

Niyonzima, G., G. Laekeman, M. Witvrouw, B.V. Poel and L. Pieters et al., 1999. Hypoglycemic, anticomplement and anti-HIV activities of Spathodea campanulata stem bark. Phytomedicine, 6: 45-49. DOI: 10.1016/S0944-7113(99)80034-8

Ofori-Kwakye, K., A.A. Kwapong and F. Adu, 2009. Antimicrobial activity of extracts and topical products of the stem bark of Spathodea campanulata for wound healing. Afr. J. Traditional, Complementary Alternative Med., 6: 168-174. DOI: 10.4314/ajtcam.v6i2.57089

Ohkawa, H., N. Oshishi and K. Yag, 1979. Assay for lipid peroxides in animal tissues by thiobarbituric acid reaction. Analytical Biochem., 95: 351-358. DOI: 10.1016/0003-2697(79)90738-3

Orhan, D.D., N. Orhan, E. Ergun and F. Ergun, 2007. Hepatoprotective effect of Vitis vinifera L. leaves on carbon tetrachloride-induced acute liver damage in rats. J. Ethnopharmacol., 112: 145-151. DOI: 10.1016/j.jep.2007.02.013

Oyaizu, M., 1986. Studies on products of browning reaction: Antioxidative activities of browning reaction prepared from glucosamine. Japanese J. Nutr. Dietet., 44: 307-315. DOI: 10.5264/eiyogakuzashi.44.307

Ramaiah, S.K., 2007. A toxicologist guide to the diagnostic interpretation of hepatic biochemical parameters. Food Chem. Toxicol., 45: 1551-1557. DOI: $10.1016 /$ j.fct.2007.06.007

Recknagel, R.O., 1983. A new direction in the study of carbon tetrachloride hepatotoxicity. Life Sci., 33: 401-408. DOI: 10.1016/0024-3205(83)90787-7

Rice-Evans, C.A., N.J. Miller, P.G. Bolwell, P.M. Bramley and J.B. Pridham, 1995. The relative antioxidant activities of plant-derived polyphenolic flavonoids. Free Radical Res., 22: 375-383. DOI: $10.3109 / 10715769509145649$ 
Rose, R., A. Banerjee and S.K. Ramaiah, 2007. Characterization of a lipopolysaccharide mediated neutrophilic hepatitis model in Sprague Dawley rats. J. Applied Toxicol., 27: 602-611. DOI: 10.1002/jat.1243

Rubinstein, D., 1962. Epinephrine release and liver glycogen levels after carbon tetrachloride administration. Am. J. Physiol., 203: 1033-1037. PMID: 13983029

Soto, C.P., B.L. Perez, L.P. Favari and J.L. Reyes, 1998. Prevention of alloxan-induced diabetes mellitus in the rat by silymarin. Comparative Biochem. Physiol., 119: 125-129. DOI: 10.1016/S0742-8413(97)00198-9
Timbrel, J., 2009. Principles of Biochemical Toxicology. 4th Edn., Informa, Boca Raton, ISBN-10: 0849373026, pp: 453.

Tsai, J.H., J.Y. Liu, T.T. Wu, P.C. Ho and C.Y. Huang et al., 2008. Effects of silymarin on the resolution of liver fibrosis induced by carbon tetrachloride in rats. J. Viral Hepat., 15: 508-514. DOI: $10.1111 / j .1365-2893.2008 .00971 . x$ 